\title{
The Effects of STEM Education on Academic Achievement in Science Courses: A Meta-Analysis
}

\section{STEM Eğitiminin Fen Bilimleri Dersinde Akademik Başarı Üzerine Etkisi: Bir Meta-Analiz Çalışması}

\author{
Şadiye KARAŞAH-ÇAKICI* \\ Özge KOL ${ }^{* *}$ \\ Süleyman YAMAN
}

Received: 15 October 2020

Research Article

Accepted: 31 March 2021

ABSTRACT: In this research, a meta-analysis was conducted to find out the effect level of STEM education on students' academic achievement in science courses. Scientific studies which were conducted and published in Turkey between January 2018 and March 2020 were reviewed in the research. As a result of the literature review, 54 studies that were suitable for the purpose of the study were reached. In analyses conducted with a statistical analysis program, effect levels were compared in terms of subject area and number of participants in addition to approaches/method used. According to the results of this research, it was concluded that STEM education was more effective in increasing students' achievement in science courses when compared with teacher-centred teaching methods. According to the results examined according to other variables discussed in the research, significant difference was found in terms of the year in which the study was conducted, the researcher's job, application period of the study and the number of participants. According to the results of the examined variables, the largest effect size was found in the field of biology, at high school level, doctoral publications, in researchers who were teachers, with 81 and above participants, in studies conducted in 2019.

Keywords: Science education, meta-analysis, academic achievement, STEM education.

ÖZ: Bu araştırmada, STEM eğitiminin öğrencilerin fen derslerindeki akademik başarıları üzerindeki etki düzeyini ortaya çıkarmak için bir meta-analiz yapılmıştır. Çalışmada Ocak 2018 - Mart 2020 tarihleri arasında Türkiye'de yürütülen ve yayınlanan bilimsel çalışmalar gözden geçirildi. Literatür taraması sonucunda araştırmanın amacına uygun 54 çalışmaya ulaşılmıştır. Bir istatistik analiz programı ile yapılan analizlerde, etki düzeyleri, kullanılan yaklaşımlar / yöntemin yanı sıra konu alanı ve katılımcı sayısı açısından karşılaştırılmıştır. Bu araştırmanın sonuçlarına göre, öğretmen merkezli öğretim yöntemlerine göre STEM eğitiminin öğrencilerin fen derslerinde başarılarını artırmada daha etkili olduğu sonucuna varılmıştır. Araştırmada ele alınan diğer değişkenlerin sonuçlara göre çalışmanın yapıldığı yıl, çalışmayı yapan kişilerin görevleri, çalışmanın uygulama süresi ve katılımcı sayısı açısından anlamlı farklılık bulunmuştur. İncelenen değişkenlerin sonuçlarına göre en büyük etki büyüklükleri biyoloji alanında, lise düzeyinde, doktora yayınlarında, öğretmen olan araştırmacılarda, 81 ve üzeri katılımcıyla, 2019 yılında yapılan çalışmalarda bulunmuştur.

Anahtar kelimeler: Fen eğitimi, meta-analiz, akademik başarı, STEM eğitimi.

\footnotetext{
* Corresponding Author: PhD Candidate, Ondokuz Mayıs University, Samsun, Turkey, karasah08sados@gmail.com, https://orcid.org/0000-0002-6673-6366

** Lecturer, Beykent University, İstanbul, Turkey, ozgekol@ beykent.edu.tr, https://orcid.org/0000-0002-3566-1074

*** Prof. Dr., Ondokuz Mayis University, Samsun, Turkey, syaman@ omu.edu.tr. https://orcid.org/0000-0001-51524945
}

Citation Information

Karaşah-Çakıcı, Ş., Kol, Ö., \& Yaman, S. (2021). The effects of STEM education on academic achievement in science courses: A meta-analysis. Kuramsal Eğitimbilim Dergisi [Journal of Theoretical Educational Science], 14(2), 264-290.

Copyright (C) 2021 by AKU

ISSN: $1308-1659$ 
Contemporary education approach aims to equip the individual with cognitive, physical and psycho-motor development. This understanding is the process of addressing the individual in all aspects and enabling the individual to reach the qualifications desired by both the individual and the society he/she is in (Yeşilyaprak, 2006). The fast developments in science and technology also change social life. Explaining and interpreting these developments, adapting to changes, enabling all fields to benefit from developments and meeting the needs of the society can be made possible by individuals who have received science education (Hançer, Şensoy, \& Yıldırım, 2003). According to McComas and Murie (2014), science education is a scientific and practical discipline related to science content, scientific process and learning, teaching and evaluating the nature of science. In order to carry out an effective science education today, science must be associated with different disciplines. Due to technological competition, economically developed countries have begun to make more investments in education in order to raise individuals working in the field of science. Developing countries, including our country, aim to participate in this competition by carrying out reform studies in education (Ministry of National Education [MEB], 2016).

The potential of having qualified individuals is the basic condition for developing and competing in all areas. Each day, there is an increase in the need for individuals who can put forward original ideas in the field of science and who have high power of inquiry and creativity. In this context, The Programme for International Student Assessment-PISA and Trends in International Mathematics and Science StudyTIMSS reports include warnings about the deficiencies in the education system so that individuals can receive education in accordance with the desired workforce qualifications (United Nations Educational, Scientific, \& Cultural Organization [UNESCO], 2015). The data below summarise the results of these exams related to science in which national and international measurements are made:

Table 1

TIMSS, PISA, TYT and LGS Exam Scores Regarding Science by Years

\begin{tabular}{lccc}
\hline TIMSS - 8th Grade & 2007 & 2011 & 2015 \\
\hline TIMSS average & 500 & 500 & 500 \\
Turkey average & 454 & 483 & 493 \\
Ranking & 31 & 21 & 21 \\
Number of participant countries & 59 & 42 & 39 \\
\hline PISA & 2009 & 2012 & 2015 \\
\hline OECD average & 495 & 501 & 493 \\
Average of all countries & 471 & 477 & 465 \\
Turkey average & 454 & 463 & 425 \\
Ranking & 42 & 43 & 54 \\
Number of participant countries & 65 & 65 & 72 \\
\hline TYT & & 2018 & 2019 \\
\hline Number of questions & & 20 & 20 \\
Average net & & 2.89 & 2.24 \\
\hline
\end{tabular}




\begin{tabular}{lcc} 
Success rate (\%) & 14.45 & 11.20 \\
\hline LGS & 2018 & 2019 \\
\hline Number of questions & 20 & 20 \\
Average net & 13.05 & 7.3 \\
Success rate $(\%)$ & 65.25 & 36.50
\end{tabular}

While 47 countries at 4th grade level participated in TIMSS 2015 study, Turkey ranked 35th among these countries and had an average science achievement of 483 points. While 39 countries at 8th grade level participated in TIMSS 2015 study, Turkey ranked 21st among these countries and had an average science achievement of 493 points. When we examined the changes in average scores of PISA science literacy field by years; we found out that there was an increase in the average of all countries and OECD average between PISA 2006 and PISA 2012, while a decrease was found in the average score of PISA 2015 conducted after PISA 2012. In the last report issued, we found that 79 countries participated, and Turkish students ranked 39th among all countries in science literacy and 30th among 37 OECD countries (OECD, 2019). Of the national exams, Basic Proficiency Test (TYT) includes 20 questions in the field of science. While the students' success rate in science in TYT, the first of which was applied in 2018, was $14.45 \%$ in 2018 , this rate was found as $11.20 \%$ in 2019 . In Transition System to High Schools (LGS), the first of which was applied again in 2018, the success rates of students in science were found to be much higher than university entrance exam. While the success rate of the students was $65.25 \%$ in 2018 , it was found as $36.50 \%$ in 2019 .

Table 2

Highest Scores Related with Science in PISA and TIMMS Exams and Turkey Average Scores

\begin{tabular}{ccccc}
\hline & PISA 2009 & PISA 2012 & PISA 2015 & PISA 2018 \\
\cline { 2 - 5 } Highest score & 575 (China) & 580 (China) & 556 (Singapore) & 590 (China) \\
Turkey & 454 & 463 & 425 & 468 \\
& TIMSS 2007 & TIMSS 2011 & TIMSS 2015 & TIMSS 2019 \\
\cline { 2 - 5 } Highest score & 567 (Singapore) & 590 (Singapore) & 597 (Singapore) & 608 (Singapore) \\
Turkey & 454 & 483 & 493 & 515 \\
\hline
\end{tabular}

When PISA 2009 results are examined, it can be seen that China got the highest score, 575 and Turkey got 454 points. According to PISA 2012 results, while China got the highest score, 580; Turkey got 463 points. According to PISA 2015 results, while Singapore got the highest score, 556 in science, Turkey got 425 points in science. According to the most recent PISA results, which was in 2018, Turkey got the highest point ever. In addition, China ranked in the first place by increasing its score in the previous years. According to TIMSS 2007 results, Singapore got the highest score, 567, in science, while Turkey got 454 points in science. According to TIMSS 2011 results, Singapore got the highest score, 590, while Turkey got 483 points. According to TIMSS 
2015 results, Singapore got the highest score, 597, while Turkey got 493 points. According to TIMSS 2019 results, Singapore got the highest score, 608, while Turkey got 515 points. The difference between Turkey and the country with the highest score decreased from 2007 to 2019, although it was a slight decrease.

As Table 2 shows, Turkey's exam results in science are below the averages of all countries and much lower than the countries that are successful in these exams. It has become inevitable for new programs to be implemented to increase the success of Turkish students in national exams besides international exams. This situation has made it necessary to make changes in programs and to develop them. Such changes made in programs should be structured in a way that suits the needs of the society and individuals (Ayas, 1995). In addition, when subjects are interconnected and sequential in physics, chemistry and biology courses, students learn more meaningfully and permanently because they can gather information from different fields and see the relationship between these better (Keskin \& Özay-Köse, 2019). For this aim, in the last decade, the Ministry of National Education also made significant changes in all teaching programs in 2013 and 2018. These changes aim to educate individuals to be able to produce information and use this information in daily life; to produce results for the problems encountered; to have a critical perspective and developed skills of entrepreneurship and communication; to be decisive; to have high empathy power and contribute to their society and the culture.

Science course, which has an important place to students in teaching the aforementioned skills, is taught between the third and eighth grades in the basic education process. When the changes in the curriculum of this teaching program made in 2018 are reviewed, it can be seen that Science, Engineering and Entrepreneurship practices are put in the units of all grades except for grade three and that skills specific for the field are taught. These skills are a) Scientific process skills, b) Life skills, c) Engineering and design skills. These skill areas include developing strategies to enable students to gain an interdisciplinary perspective to problems, to bring individuals to a level of being able to make inventions and innovations, to enable them to create a new product by evaluating the information, skills and experiences they have and how they can give added value to the products they create through integrating science with mathematics, technology and engineering (Science, Technology, Engineering, Mathematics -STEM) (MEB, 2018).

According to Y1ldırım (2016), "STEM education is a contemporary approach that aims to use integrative approach while educating individuals and teaching them the necessary skills in daily life and scientific process that can meet the needs by equipping them with 21st-century skills." The word STEM is an abbreviation formed with the first letters of the words. In Turkish, it has been abbreviated as FeTeMM by using the first letters of the fields of Science (Fen), Technology (Teknoloji), Engineering (Mühendislik) and Mathematics (Matematik) (Yılmaz, Yiğit-Koyunkaya, Güler, \& Güzey, 2017). It can be seen that while FeTeMM was frequently used in the early times when this concept was first studied in our country, the abbreviation STEM is used more today.

STEM education is accepted as an integrative approach that helps the individual associate the experiences in daily life with the teaching of the course. This education is important to educate individuals who can be aware of the developments in the international arena, suggest new inventions and adapt to new developments. In this 
respect, STEM education has a structure that can be applied in each stage of education (Aydagül \& Terzioğlu, 2014; Breiner, Harkness, Johnson, \& Koehler, 2012; Bybee, 2010). STEM education gained momentum with European Commission, Scientific and Technological Research Council of Turkey (TÜBITAK) and the institutions they cooperate with. STEM education is also applied in private schools, and supportive studies are conducted in the field of STEM in higher education (TÜSİAD, 2017) because with STEM education, academic disciplines can be associated with daily life subjects. This way, it is possible not to restrict STEM subjects to school only. It is possible to educate individuals with high scientific creativity who can compete well in the global economy and make innovations that will put society into action (Sanders, 2009). "Science, technology and innovation" article in the "competitive production and efficiency" section in Eleventh Development Plan (Turkey Presidency of the Strategy and Budget, 2019) emphasizes giving individuals the skills to generate information and use the generated information by creating an actively continuing research and innovation climate and increasing research and development and innovation studies to support services with high value-added products. In addition, in the "education" article of "qualified individual, strong society" section of this plan, an emphasis was made to educate individuals who have the characteristics of entrepreneurship and innovation with feelings of responsibility and self-confidence, internalized national culture and democratic values and who have developed perception and problem-solving skills. In this context, it can be said that science curriculum, which aims to develop engineering and entrepreneurship skills in addition to science, has a strategic significance.

When the literature is reviewed, it can be seen that a large number of studies have been conducted about STEM education by a large number of researchers who have realized the above-mentioned needs. Some of these studies have discussed the effects of STEM activities on academic achievement. Meta-analysis has also been conducted to find out the effect levels of these studies. In a study in which the effects of STEM education on students' success were examined, Becker and Park (2011) concluded that the Cohen's d effect size of 28 scientific research was .63. This means moderate effect size. In their study, Mustafa, Ismail, Tasir and Said (2016) conducted a meta-analysis of 11 studies in which science success in STEM education was discussed. In a study by Belland, Walker, Kim, and Lefler (2017), it was found that computer-based education in STEM disciplines had an average Hedges' $g$ effect size of .46. In a meta-analysis study by Kim, Belland, and Walker (2018), it was found that computer-based STEM education had a Hedges's g effect size of .39 on cognitive outputs in problem-based learning. Saraç (2018) found that STEM education had a Hedges' g effect size of .44. As can be seen in the studies above, it has been found that, in general, STEM education had a small or moderate effect size on the academic success of students. In this context, the present study aims to conduct a meta-analysis to statistically show the effect level of STEM education on students' academic success by examining studies with experimental and control groups conducted after 2018. The sub-problems discussed in the study are as follows:

Does the effect of STEM education on students' academic achievement differ in terms of

- The number of participants,

- Types of publication, 
- Application times,

- Application areas,

- Levels of education and,

- The years in which the applications were made?

\section{Method}

The present research is a meta-analysis. Meta-analysis is the statistical gathering of the findings of studies conducted independently from each other. A meta-analysis aims to ask a question and use the studies conducted as data to answer the question (Lodico, Spaulding, \& Voegtle, 2006). In other words, meta-analysis is a method that aims to reach a new synthesis by examining the results of studies conducted following a predetermined subject and purpose (Cooper, 2015). Meta-analysis is a statistical method used for combining or comparing effect sizes or probability levels obtained from at least two studies (Rosenthal, 1984). In addition, this method is a literature review method in which statistical methods are used to bring research findings together and analyse them (Durlak \& Lipsey, 1991). Meta-analysis is an analysis method that combines the results of many small and different individual studies using one or more statistical methods and provides information (Olkin, 1996).

\section{Data Collection}

The studies reviewed in the present research include the master's theses, doctorate theses and articles published in journals with reviewers on "STEM education" in Turkey between 2018 and 2020. To reach doctorate and master's theses, keywords related to the research's main independent variable, such as 'STEM' and 'FeTeMM', were used on the website of the Council of Higher Education (YÖK) Thesis Centre. 243 theses were reached in this study. Since the full texts of 2 studies which were limited for viewing could not be reached, the authors of the theses were contacted, and the data required for analysis were requested; however, the authors did not respond. The suitability of the data of 241 theses reached for meta-analysis was examined, and 201 theses were not included in this meta-analysis for reasons such as not having a relevant field of study, study subject and study group. Therefore, 42 master and doctorate theses were included in the meta-analysis.

In order to access articles published in national and international Turkish journals between January 2018 and February 2020, Google Academic and ULAKBIM Social Sciences Database were used. 32 studies were found as a result of this research. Since one of these studies was already added in the study as a master's thesis and since the data of 19 of these studies were not suitable for analysis, we excluded them from the analysis. As a result of the research, a total of 12 articles published in journals were included in the study. Since two experimental and one control group were used in one of these articles, they were included in the analysis as separate studies. As a result, a total of 54 studies, master's and doctorate theses and scientific articles, which had relevant data for meta-analysis and in which STEM education was used, were analysed in this research.

\section{Analysis Characteristics}

The following criteria were used in the selection of the studies included in the present study for meta-analysis: 
- Researches conducted in one of the subjects covered in Science, Biology, Chemistry or Physics courses,

- Theses conducted in Turkey between 2018 and 2019; articles published in Turkey between 2018 and 2020,

- Studies conducted in English or Turkish,

- Master's theses and doctorate theses and articles published in journals with scientific reviewers,

- Studies in which academic achievement was dependent variable,

- Studies with experimental or semi-experimental design,

- Studies in which one of the STEM practices or activities was applied on the experimental group and in which teacher-centred or one of the approaches in existing teaching programs was used in the control group,

- Studies in which values are required for analyses such as arithmetic mean, standard deviation, number of students, t-test value, and academic achievement scores of the experimental and control groups were given.

\section{Data Coding}

In meta-analysis studies, coding the studies included in the research is an important stage. The data analysed should be coded correctly for minimum erroneous results. For this purpose, it is crucial to ensure scorer reliability. In order to ensure this, researchers should enter the studies to be analysed separately in the coding form and control all data after they are entered. Thus, a coding form consisting of three parts was formed to minimize the error rate in data. The first part constitutes the identity of the study. The identity of the research shows the number, title, publication year and publication type of the study. In the content of the study part, which is the second part of the coding form, there is information about the subject area in which STEM education was applied (physics, chemistry, biology, science) and level of education and the duration of the experimental study. The third part includes study data such as arithmetic mean, $\mathrm{t}$-value, standard deviation and the number of participants.

The data were entered in the coding form independently by three different researchers. Two of these researchers are continuing their doctorate education in the field of science, while the other researcher is working as a faculty member in the related field. Miles and Huberman's (1994) formula were used in finding out the match percentage of the data researchers coded independently. The consistency level of the researchers' codes was found as $96 \%$. For non-matching codes, the data were analysed together and coding was continued until a consensus was reached. Data on which no consensus was reached was removed from the coding form. Considering that $70 \%$ and higher match is considered as sufficient in such coding (Yıldırım \& Şimşek, 2011), it was concluded that the reliability level of the coded data was sufficient.

\section{Variables of the research}

\section{Dependent Variable}

The dependent variable examined in the research is the academic achievement scores of the students in science courses. 


\section{Independent Variables}

The main independent variable of the research is STEM education applied to the experimental group. For this purpose, STEM studies were included in the study. In addition, teaching/learning approaches the effects of which were examined on the control group are another independent variable of the research. In the applications conducted on the control group, the students should be passive, while the teachers should be active; in other words, they should be teacher-centred methods. The other independent variables in the research were the students' level of education (primary school, secondary school, high school and university), jobs of the researchers (academic or teacher/other), study sample, duration of the experimental study and the fields of the courses on which applications were made (physics, chemistry, biology or science). In studies conducted within the context of science courses in primary schools and secondary schools, separate coding was made as physics, chemistry or biology; and since more than one field was included in two studies, the coding was made as science.

\section{Data Analysis}

In a meta-analysis, the studies examined should have some criteria. In the research, statistical data such as the number of students, arithmetic means, standard deviations were examined in studies which met the criteria. When the arithmetic means of students' academic achievement is obtained with different scales, meta-analysis group difference is conducted with study effect method (Cohen, 1988; Huffcutt, 2002; Lipsey \& Wilson, 2001). In other words, in research effect method, transactions are made on the differences between average academic achievement scores of the experimental and control group (Hunter \& Schmidt, 2004). A "d" value is obtained after this transaction. This " $d$ " value represents effect size. Effect size is obtained by the standard deviation, arithmetic mean, F, $\mathrm{t}$ or $\mathrm{r}$ values of studies conducted independently (Çetink1l, 2017). This value's being negative means that the control group's average score is higher than the experimental group. In comparison, positive means that the experimental group's average score is higher than the control group (Özdemirli, 2011). In this research, Cohen's d values calculated by dividing the differences between the mean academic achievement scores of the experimental and control groups by the combined standard deviation value were taken into consideration (Schulze, 2004). Effect size metric in the research was standardized differences in means which is also known as Cohen d. Within the scope of this research, the significance level of the statistics for Cohen's d value obtained from studies conducted independently on the subject was chosen as .05. In graphs, standard means given automatically by CMA program were used. Effect size classification based on Cohen's (1988, p. 40) averages is as follows:

\section{- small $.20 \quad$ - medium $.50 \quad$ - large .80}

In analyses, effect size is calculated separately for each study. Heterogeneity test is conducted to explain the different effect size in each study. Chi-square homogeneity test ( $Q$ statistic) is used to test whether there is actual heterogeneity in the studies included in the research. Also, the frame is examined using graphs and tables outside heterogeneity. In addition, standard deviations not dependent on sample size can also be used for heterogeneity.

Since the information obtained as a result of heterogeneity test will also be used to select the model that will be used in calculating the general effect, it is vital for the 
study. $\mathrm{p}$ value and $\mathrm{Q}$ value are obtained as the output of heterogeneity test. Of these values, if the $\mathrm{p}$ value is smaller than the .05 significance value or the $\mathrm{Q}$ value is smaller than the value that corresponds to the degree of freedom of the Chi-square table, it is understood that the data examined has a heterogeneous structure. When this result occurs, it is recommended for the data to be analysed according to Random Effects Model (REM). If the $\mathrm{p}$ value is larger than the .05 significance value or the $\mathrm{Q}$ value is larger than the value in Chi-square table, it is understood that the meta-analysis examined has a homogeneous structure, and in this case, it is recommended for the data to be analysed according to Fixed Effects Model (FEM) (Dinçer, 2014).

If effect value differs, this is assumed to result from a sampling error (Borenstein, Hedges, Higgins, \& Rothstein, 2009). In the model, it is accepted that the variance between the study results is due to data associated with each other (OkursoyGünhan, 2009). REM is preferred when the studies are not homogeneous (Durlak, 1995). This is a model which enables concluding by taking into account the variance between the variance of the studies and other studies (Okursoy-Günhan, 2009). While standard deviation's state of being zero is calculated in REM, standard deviation's state of not being zero is calculated in FEM.

For this reason, REM has a more general use when compared with FEM (Murphy, 2003). For this research, Q was calculated as 685.98, while $\mathrm{p}$ was calculated as .000. According to this result, $\mathrm{p}$ value of the study was found as a value smaller than the critical .05. This shows that the studies examined in the meta-analysis have a heterogeneous structure. For this reason, the analyses were conducted according to REM in the study. Comprehensive Meta-Analysis (CMA) program was used in the analysis of the data obtained from the study and in forming the tables, graphs and figures.

\section{Results}

This section includes the analysis results of the data obtained as a result of combining research problems with meta-analysis method.

\section{Effect Size Results of the Studies Examined in the Research}

To calculate the effect sizes of the studies in which STEM education is applied, first of all, the meta-analysis model to be used should be determined. For this purpose, the homogeneity of STEM education was tested with FEM and REM for the data within the context of the study. Based on these procedures, the results regarding the homogeneity and overall effect sizes of the studies are given in Table 3 below.

Table 3

Results Related with Effect Sizes of the Studies According to Fixed Effects and Random Effects Models

\begin{tabular}{cccccccc}
\hline & $\begin{array}{c}\text { Average } \\
\text { effect size } \\
(\text { ES })\end{array}$ & $\begin{array}{c}\text { Degree of } \\
\text { freedom } \\
(\mathrm{df})\end{array}$ & $\mathrm{I}^{2}$ & $\begin{array}{c}\text { Homogeneit } \\
\text { y level (Q) }\end{array}$ & $\begin{array}{c}\text { Standard } \\
\text { Error } \\
(\mathrm{Se})\end{array}$ & \multicolumn{2}{c}{ 95\% Confidence Interval for } \\
Lower Limit & Upper Limit \\
\hline FEM & 1.32 & & & & .05 & 1.24 & 1.41 \\
REM & 1.48 & 44 & 92.66 & 599.17 & .17 & 1.14 & 1.81 \\
\hline
\end{tabular}


When the studies were examined according to REM, average effect size value was found as 1.32. According to the homogeneity test results, the homogeneity of the effect sizes of studies included in the research, Q statistical value was found as 599.17. According to this value, effect sizes of the studies included in the research are heterogeneous. This result shows that the analyses of the studies examined should be made according to REM because heterogeneity test $\mathrm{Q}$ statistical value is within the range of 55.75 and 67.50 , corresponding to $\mathrm{df}=44$ value at $95 \%$ confidence interval in the table of $\chi 2$ critical values. Since $Q=599.17$ value is much higher than this value, it was concluded that the research data showed a heterogeneous structure. According to heterogeneity test results, if the research result is significant, REM should be used (Dinçer, 2014).

Analyses conducted according to REM show that the upper limit of $95 \%$ confidence interval is 1.81 , while lower limit is 1.14 and average effect size is 1.48 . This value shows that the effect sizes of the studies included in the study show homogeneity according to REM. Effect sizes were calculated in terms of standardized difference of means. The standardized mean difference can be compared between studies regardless of the sample and can be applied Cohen $d$ to homogeneity testing for meta-analysis as long as it specifies the size and direction of the study (Kulinskaya, Dollinger, \& Bjørkestøl, 2011). Effect size distribution of all the studies included in the study is given in Table 4 .

Table 4

Distribution of Effect Size Values of the Studies

\begin{tabular}{c|ccccccccccccccc}
\hline $\mathrm{No}$ & $\mathrm{ES}$ & $\mathrm{Se}$ & $\mathrm{S}^{2}$ & $\mathrm{p}$ & $\mathrm{No}$ & $\mathrm{ES}$ & $\mathrm{Se}$ & $\mathrm{S}^{2}$ & $\mathrm{p}$ & $\mathrm{No}$ & $\mathrm{ES}$ & $\mathrm{Se}$ & $\mathrm{S}^{2}$ & $\mathrm{p}$ \\
\hline 1 & 4.09 & .24 & .06 & .000 & 16 & 1.47 & .34 & .12 & .000 & 31 & 3.18 & .24 & .06 & .000 \\
\hline 2 & -.26 & .33 & .11 & .435 & 17 & .95 & .32 & .10 & .003 & 32 & 3.91 & .60 & .37 & .000 \\
\hline 3 & .78 & .30 & .09 & .009 & 18 & .99 & .32 & .10 & .002 & 33 & 2.55 & .43 & .18 & .000 \\
\hline 4 & .87 & .39 & .15 & .025 & 19 & .99 & .47 & .22 & .038 & 34 & 2.70 & .35 & .12 & .000 \\
\hline 5 & 5.08 & .65 & .42 & .000 & 20 & .29 & .28 & .08 & .289 & 35 & 7.01 & .59 & .35 & .000 \\
\hline 6 & 1.70 & .35 & .12 & .000 & 21 & .79 & .27 & .07 & .004 & 36 & 1.64 & .30 & .09 & .000 \\
\hline 7 & 1.87 & .30 & .09 & .000 & 22 & .76 & .25 & .06 & .003 & 37 & .62 & .32 & .11 & .056 \\
8 & .84 & .29 & .08 & .004 & 23 & .74 & .28 & .08 & .008 & 38 & .23 & .37 & .13 & .536 \\
\hline 9 & 1.71 & .20 & .04 & .000 & 24 & .95 & .33 & .11 & .004 & 39 & 1.11 & .38 & .15 & .004 \\
\hline 10 & 1.51 & .28 & .08 & .000 & 25 & .84 & .38 & .15 & .028 & 40 & .76 & .25 & .06 & .002 \\
\hline 11 & 3.48 & .34 & .12 & .000 & 26 & 1.18 & .43 & .18 & .006 & 41 & .89 & .43 & .18 & .037 \\
\hline 12 & .53 & .25 & .06 & .034 & 27 & .79 & .27 & .07 & .003 & 42 & 1.04 & .33 & .11 & .002 \\
\hline 13 & 1.07 & .17 & .03 & .000 & 28 & .01 & .29 & .09 & .985 & 43 & 2.35 & .40 & .16 & .000 \\
\hline & .32 & .31 & .10 & .308 & 29 & 2.66 & .37 & .14 & .000 & 44 & .81 & .21 & .04 & .000 \\
\hline
\end{tabular}


Table 4 shows the effect sizes, standard deviation, variance and $\mathrm{p}$ values of the 45 studies included in the study. When Table 3 is examined, it can be seen that while the smallest effect size is -.26 , the largest effect size is 7.01. Effect sizes of the study are between these two values, and in general, they are grouped between .00 and 1.00. Besides, it was found that the range of effect size values of 45 studies examined in the study was 7.27.

Figure 1

Forest Plot Showing the Distribution of Effect Size Values of Studies

\begin{tabular}{|c|c|c|c|c|c|c|c|}
\hline \multirow[t]{2}{*}{ study nems } & \multicolumn{7}{|c|}{ statictioc for sooh ctudy } \\
\hline & $\begin{array}{l}\text { sta dift } \\
\text { In masne }\end{array}$ & $\begin{array}{l}\text { standard } \\
\text { orror }\end{array}$ & Varlanos & $\begin{array}{l}\text { Lower } \\
\text { Ilmit }\end{array}$ & $\begin{array}{l}\text { Upper } \\
\text { Ilmit }\end{array}$ & Z-Valus & p-Valus \\
\hline $01 \mathrm{~A}$ & 4,092 & 0.238 & 0,057 & 3,625 & 4,559 & 17,176 & 0,000 \\
\hline $02 \mathrm{a}$ & 0,258 & 0,330 & 0,109 & $-0,505$ & 0,399 & 0,781 & 0,435 \\
\hline 03a & 0,775 & 0.295 & 0,087 & 0,197 & 1,354 & 2,626 & 0,009 \\
\hline 04a & 0.870 & 0,389 & 0,151 & 0,108 & 1,632 & 2.237 & 0,025 \\
\hline $06 \mathrm{a}$ & 5,082 & 0,650 & 0,423 & 3,807 & 6,356 & 7,815 & 0,000 \\
\hline $07 \mathrm{a}$ & 1,701 & 0,348 & 0,121 & 1,019 & 2,383 & 4,898 & 0,000 \\
\hline $08 \mathrm{a}$ & 1,866 & 0,303 & 0,092 & 1,272 & 2,460 & 6,155 & 0,000 \\
\hline $10 \mathrm{~s}$ & 0,838 & 0.289 & 0,084 & 0.271 & 1,405 & 2896 & 0,004 \\
\hline $11 \mathrm{a}$ & 1,706 & 0.203 & 0,041 & 1,309 & 2,103 & 8,422 & 0,000 \\
\hline $12 \mathrm{a}$ & 1,507 & 0.281 & 0,079 & 0,956 & 2,058 & 5,361 & 0,000 \\
\hline $13 \mathrm{a}$ & 3,478 & 0,344 & 0,118 & 2.804 & 4,152 & 10,116 & 0,000 \\
\hline $14 \mathrm{a}$ & 0,526 & 0.248 & 0,061 & 0,040 & 1,012 & 2,122 & 0,034 \\
\hline 150 & 1,065 & 0,170 & 0,029 & 0,731 & 1,399 & 6,252 & 0,000 \\
\hline 169 & 0,320 & 0,314 & 0,099 & 0,296 & 0,937 & 1,019 & 0,308 \\
\hline $18 \mathrm{a}$ & 0,303 & 0,304 & 0,093 & 0,294 & 0,500 & 0,966 & 0,319 \\
\hline 190 & 1,473 & 0,344 & 0,118 & 0,799 & 2,147 & 4,282 & 0,000 \\
\hline $20 \mathrm{~s}$ & 0,947 & 0,318 & 0,101 & 0,324 & 1,571 & 2,960 & 0,003 \\
\hline $22 \mathrm{a}$ & 0,993 & 0,320 & 0,102 & 0,367 & 1,619 & 3,107 & 0,000 \\
\hline 230 & 0,985 & 0,474 & 0.224 & 0,057 & 1,913 & 2,080 & 0,038 \\
\hline $24 a$ & 0,292 & 0.275 & 0,076 & 0.247 & 0,832 & 1,061 & 0.289 \\
\hline 250 & 0,793 & 0.273 & 0,074 & 0,258 & 1,328 & 2,905 & 0,004 \\
\hline 269 & 0,755 & 0.254 & 0,054 & 0.258 & 1,252 & 2,979 & 0,003 \\
\hline $30 \mathrm{~s}$ & 0,739 & 0.279 & 0,078 & 0,192 & 1,285 & 2,650 & 0,008 \\
\hline $31 \mathrm{~A}$ & 0,950 & 0,326 & 0,106 & 0,311 & 1,588 & 2,915 & 0,004 \\
\hline $32 \mathrm{a}$ & 0,835 & 0,381 & 0,145 & 0,089 & 1,581 & 2,194 & 0,028 \\
\hline 33a & 1,178 & 0,425 & 0,181 & 0,345 & 2.011 & 2,772 & 0,006 \\
\hline $34 \mathrm{a}$ & 0,789 & 0,268 & 0,072 & 0.263 & 1,314 & 2.942 & 0,003 \\
\hline 350 & 0,005 & 0,292 & 0,085 & 0,567 & $0,5 \pi 7$ & 0,018 & 0,985 \\
\hline 369 & 2661 & 0,367 & 0,135 & 1,942 & 3,390 & 7,252 & 0,000 \\
\hline $37 \mathrm{a}$ & 0.207 & 0,357 & 0,128 & 0,493 & 0,507 & 0,579 & 0,563 \\
\hline 390 & 3,182 & 0.240 & 0,057 & 2,713 & 3,652 & 13,275 & 0,000 \\
\hline $40 \mathrm{~s}$ & 3,913 & 0,604 & 0,365 & 2,729 & 5,097 & 6,479 & 0,000 \\
\hline $41 \mathrm{a}$ & 2,548 & 0,426 & 0,181 & 1,714 & 3,382 & 5,987 & 0,000 \\
\hline $42 \mathrm{a}$ & 2,703 & 0,346 & 0,120 & 2025 & 3,381 & 7,816 & 0,000 \\
\hline $43 \mathrm{~s}$ & 7,012 & 0,590 & 0,349 & 5,855 & 8,169 & 11,876 & 0,000 \\
\hline 44a & 1,642 & 0,301 & 0,091 & 1,052 & 2.232 & 5,453 & 0,000 \\
\hline $45 \mathrm{a}$ & 0,618 & 0,324 & 0,105 & 0,016 & 1,253 & 1,910 & 0,058 \\
\hline $46 a$ & 0.227 & 0,366 & 0,134 & 0,491 & 0,945 & 0,618 & 0,538 \\
\hline $47 \mathrm{a}$ & 1,108 & 0,381 & 0,146 & 0,360 & 1,855 & 2,904 & 0,004 \\
\hline 48a & 0,763 & 0.246 & 0,060 & 0.281 & 1,244 & 3,102 & 0,002 \\
\hline 490 & 0,894 & 0,430 & 0,184 & 0,052 & 1,736 & 2,082 & 0,037 \\
\hline $50 \mathrm{~s}$ & 1,040 & 0,334 & 0,112 & 0,385 & 1,695 & 3,111 & 0,000 \\
\hline $52 \mathrm{a}$ & 2,352 & 0,396 & 0,157 & 1,575 & 3,128 & 5,937 & 0,000 \\
\hline 53a & 0,812 & 0.211 & 0,044 & 0,400 & 1,225 & 3,859 & 0,000 \\
\hline 542 & 2.251 & 0,343 & 0,118 & 1,578 & 2,924 & 6,550 & 0,000 \\
\hline & 1,477 & 0,170 & 0,029 & 1,144 & 1,810 & 8,706 & 0,000 \\
\hline
\end{tabular}

std diff in mosine and $95 \% \mathrm{Cl}$

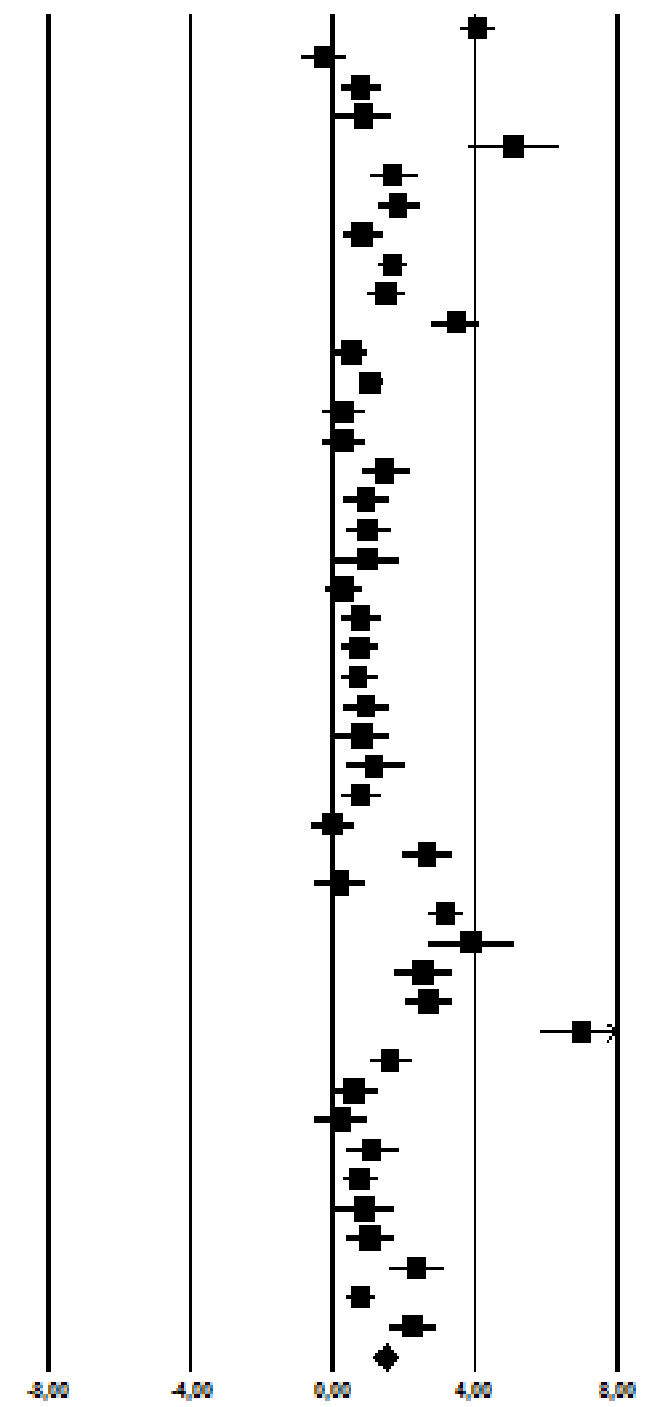

Figure 1 shows the effect sizes of studies in which STEM education was applied to students' academic achievement scores. Effect sizes were calculated in terms of standardized difference of means. Effect sizes of the studies range between -.26 and 7.01. While the study with the lowest effect size was Neccar's (2019) study, the study with the highest effect size was Tirmac1's (2019) study with 7.01. All of the 45 studies except one had positive effect size. The figure below shows the normality distribution table of the studies examined in the research. 
Figure 2

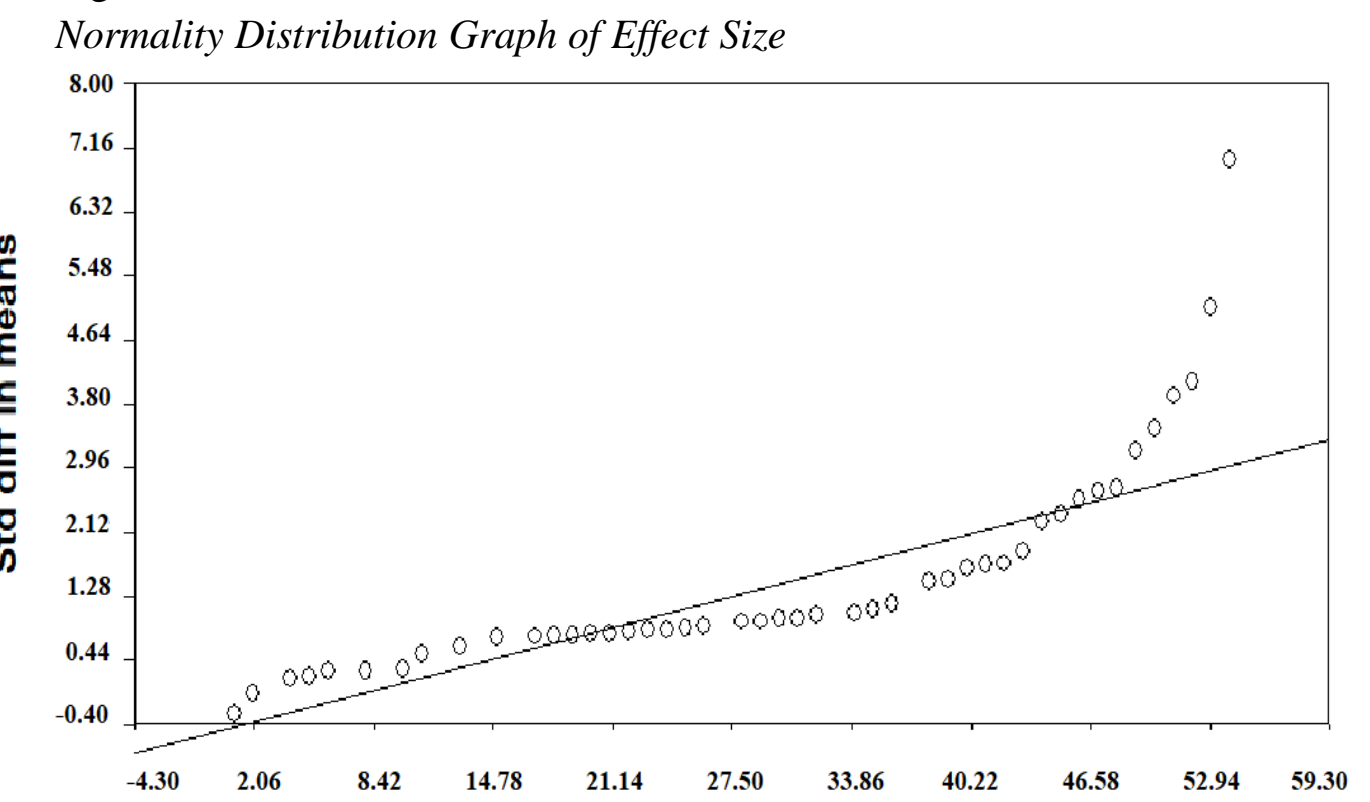

Since the effect size values of the studies included in the study gathered around normal distribution line in general, it can be said that the studies were normally distributed. The figure below shows the funnel plot showing the distribution of effect sizes of the studies in the research.

\section{Figure 3}

\section{Funnel Plot of Effect Sizes}

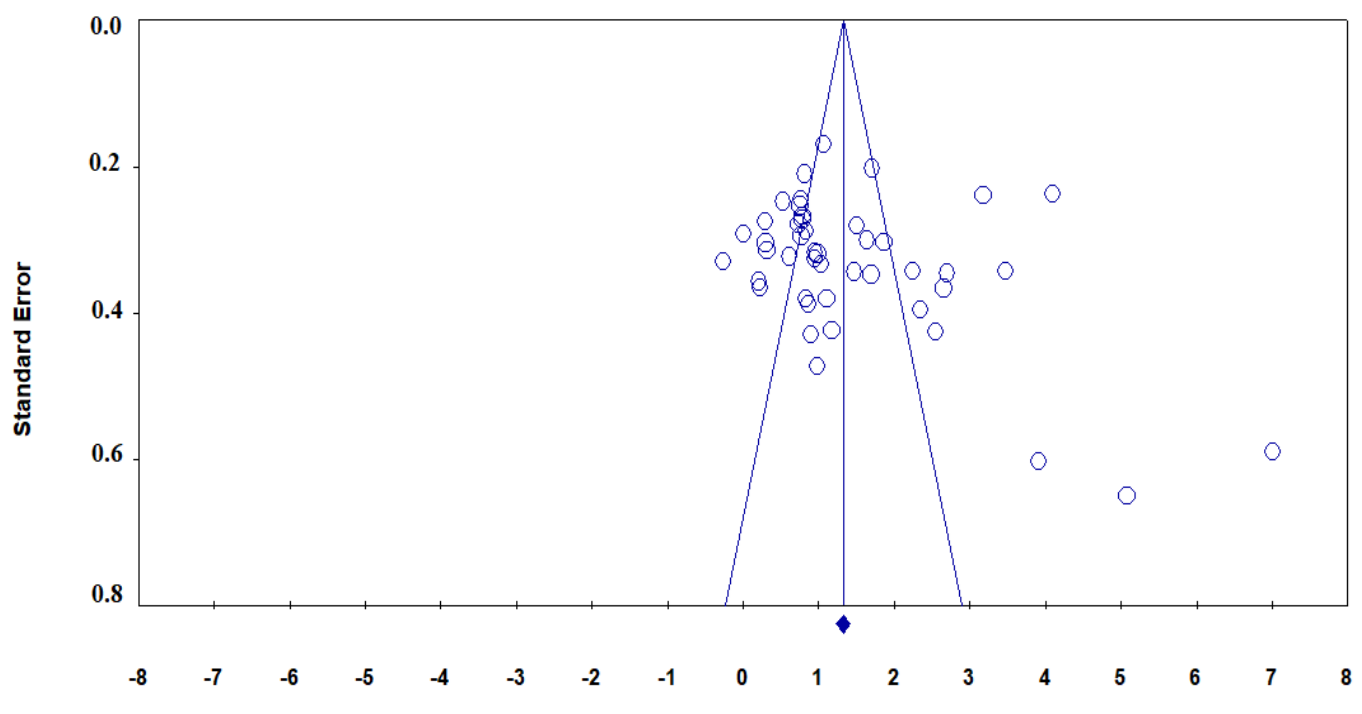

When the plot is examined, it can be seen that the studies do not show an asymmetric distribution; in other words, it can be seen that the effect sizes of the studies intensify on both sides. This plot shows that there is no publication bias in the research. In studies with publication bias, a distorted and asymmetric distribution is expected in the plot (Üstün \& Eryılmaz, 2014). According to data in this plot, corrected average effect size was found as 1.32. These data mean that publication bias is low in the study.

Moderator analysis enables the differences between subgroups to determine the differences between the average effect sizes of the variables (Littel, Corcoran, \& Pillai, 2008). The statistical significance of the difference between moderator variables is 
tested with the Q statistics method (Hedges \& Olkin, 1980). In this method, the Q value is divided into two as Qbetween $(\mathrm{Qb})$ and Qwithin $(\mathrm{Qw})$ and executed as two different values (Borenstein et al., 2009; Hedges \& Olkin, 1980). In this research, subgroup data were calculated using a single Q value. Subgroup analyses can help better understand which subgroups included in the study affect effect sizes and determine whether differences occur between these groups.

\section{Study}

Effect Size Results According to Independent Variables Examined in the

Whether STEM education affects students' academic achievement is examined in the tables below comparatively in terms of different independent variables. Table 5 shows results about whether the effect sizes of the studies differ according to publication types.

Table 5

Effect Size Differences of the Studies According to Publication Types

\begin{tabular}{|c|c|c|c|c|c|c|c|}
\hline \multirow{2}{*}{ Variable } & \multirow{2}{*}{ Q } & \multirow{2}{*}{$\mathrm{p}$} & \multirow{2}{*}{ ES } & \multirow{2}{*}{$\mathrm{n}$} & \multirow{2}{*}{$\mathrm{Se}$} & \multicolumn{2}{|c|}{$\mathrm{ES}(\% 95 \mathrm{CI})$} \\
\hline & & & & & & Lower limit & Upper limit \\
\hline Study & .86 & .65 & & & & & \\
\hline Article & & & 1.38 & 8 & .43 & .53 & 2.22 \\
\hline Master's thesis & & & 1.45 & 33 & .20 & 1.05 & 1.85 \\
\hline Doctorate thesis & & & 1.90 & 4 & .48 & .97 & 2.84 \\
\hline
\end{tabular}

When Table 5 is examined, the result that approximately $73 \%$ of all the studies conducted on STEM education were master's theses is remarkable. This is followed by articles with approximately $18 \%$. The type of study least conducted on STEM is doctorate theses with $9 \%$. From the Chi-square tables of the studies, it was found that the critical value was 5.99 according to two degrees of freedom in $95 \%$ confidence interval. According to the type of studies, the homogeneity value (Q) of the studies, which were considered as three subgroups, was found as .86. Since the homogeneity value between the groups was smaller than the critical value, no statistically significant difference was found between the publication types STEM studies were conducted with in terms of academic achievement. According to the results of analyses, the largest effect size was found in doctorate theses with 1.90; while the smallest effect size was found in articles with 1.38. Effect size of master's theses was found to be smaller than articles (1.45).

Table 6

Findings Related to the Effect Sizes of Publication Years of Studies

\begin{tabular}{lccccccc}
\hline Variable & $\mathrm{Q}$ & $\mathrm{p}$ & $\mathrm{ES}$ & $\mathrm{n}$ & $\mathrm{Se}$ & \multicolumn{2}{c}{ ES (\%95 CI) } \\
\hline Year & 9.19 & .002 & & & & & \\
\hline 2018 & & & .91 & 13 & .14 & .64 & 1.17 \\
2019 & & 1.74 & 32 & .24 & 1.27 & 2.20 \\
\hline
\end{tabular}


When Table 6 is examined, it can be seen that $71 \%$ of the studies were published in 2019, while 29\% were published in 2018. According to the analysis results, while effect size value of the studies published in 2019 was 1.74; the effect size value of the studies published in 2018 was .91. In Chi-square table, the critical value of these studies was found as 3.84 according to $95 \%$ confidence interval. Homogeneity value (Q) between groups formed in terms of the years of studies was found as 9.19. Since the homogeneity value between the groups was higher than the critical value, a statistically significant difference was found between academic achievement in terms of years of studies. In light of the findings, it can be said that academic achievement was found to be higher in studies conducted in 2019 when compared with the year 2018.

Table 7

Findings Related with the Effect Sizes of the Jobs of the Researchers

\begin{tabular}{|c|c|c|c|c|c|c|c|}
\hline \multirow{2}{*}{ Variable } & \multirow{2}{*}{ Q } & \multirow{2}{*}{$\mathrm{p}$} & \multirow{2}{*}{$\mathrm{ES}$} & \multirow{2}{*}{$\mathrm{N}$} & \multirow{2}{*}{$\mathrm{Se}$} & \multicolumn{2}{|c|}{ ES (\%95 CI) } \\
\hline & & & & & & Lower Limit & Upper Limit \\
\hline Researcher & 8.03 & .045 & & & & & \\
\hline Academic & & & 1.32 & 3 & 1.06 & -.77 & 3.40 \\
\hline Teacher & & & 1.71 & 29 & .23 & 1.26 & 2.15 \\
\hline Multiple Researchers & & & 1.03 & 7 & .28 & .48 & 1.57 \\
\hline Unspecified & & & .91 & 6 & .18 & .55 & 1.26 \\
\hline
\end{tabular}

When Table 7 is examined, it can be seen that $64.44 \%$ of the studies were conducted by teachers, $6.66 \%$ were conducted by academics, $13.32 \%$ were conducted by researchers who did not specify their jobs and $15.55 \%$ were conducted by multiple researchers. According to the results of the analyses, the largest effect size was found in teachers with 1.71; while the smallest effect size was found in researchers whose jobs were not specified with .91 . The critical value of the Chi-square tables of the studies was found as 7.81. Homogeneity value (Q) between groups formed according to the jobs of researchers was found as 8.03. Since the $\mathrm{Q}$ value, which is the homogeneity value between the groups, was larger than the critical value, significant difference was found according to the job of researchers in terms of academic achievement. In the light of findings, it can be said that academic achievement is higher in studies conducted by teachers when compared with other jobs.

Table 8

Findings Related to the Effect Sizes of the Field the Study was Conducted in

\begin{tabular}{|c|c|c|c|c|c|c|c|}
\hline \multirow{2}{*}{ Variable } & \multirow{2}{*}{ Q } & \multirow{2}{*}{$\mathrm{p}$} & \multirow{2}{*}{$\mathrm{ES}$} & \multirow{2}{*}{$\mathrm{n}$} & \multirow{2}{*}{$\mathrm{Se}$} & \multicolumn{2}{|c|}{$\mathrm{ES}(\% 95 \mathrm{CI})$} \\
\hline & & & & & & Lower Limit & Upper Limit \\
\hline Field & 7.29 & .06 & & & & & \\
\hline Biology & & & 1.68 & 7 & .38 & .94 & 2.42 \\
\hline Science & & & .76 & 4 & .25 & .28 & 1.24 \\
\hline Physics & & & .59 & 9 & .24 & .12 & 2.05 \\
\hline Chemistry & & & .17 & 5 & .41 & .36 & 1.98 \\
\hline
\end{tabular}


In Table 8, when STEM education was compared in terms of the field it was applied in, the highest rate was found to be associated with physics subjects with $64.44 \%$. Studies followed this in biology with $15.55 \%$ and with studies in the field of chemistry with $11.11 \%$. Since it was not included in a basic field category, it was found that $8.88 \%$ of the studies were conducted in the category of science, which is the name of the course in secondary school. According to the results of analyses, it was found that the largest effect size was found in studies conducted in the field of biology with 1.68; while the lowest effect size was found in studies conducted in the field of science with .76. According to Chi-square table, the critical value of the studies in $95 \%$ confidence interval was found as 7.81. The homogeneity value (Q) between groups formed according to subject area was found as 7.29. Since the $Q$ value was smaller than the critical value, it can be said that there is no statistically significant difference according to subject area in terms of academic achievement.

Table 9

Findings Related with the Effect Sizes of the Education Level the Study was Conducted in

\begin{tabular}{|c|c|c|c|c|c|c|c|}
\hline \multirow{2}{*}{ Variable } & \multirow{2}{*}{$\mathrm{Q}$} & \multirow{2}{*}{$\mathrm{p}$} & \multirow{2}{*}{ ES } & \multirow{2}{*}{$\mathrm{n}$} & \multirow{2}{*}{$\mathrm{Se}$} & \multicolumn{2}{|c|}{$\mathrm{ES}(\% 95 \mathrm{CI})$} \\
\hline & & & & & & Lower Limit & Upper Limit \\
\hline Level & 5.14 & .16 & & & & & \\
\hline Primary & & & 1.47 & 2 & .34 & .80 & 2.15 \\
\hline Secondary & & & 1.53 & 35 & .22 & 1.11 & 1.95 \\
\hline High School & & & 1.63 & 4 & .31 & 1.01 & 2.24 \\
\hline University & & & .94 & 4 & .22 & .51 & 1.37 \\
\hline
\end{tabular}

When Table 9 is examined, it was found that the highest rate according to the education level STEM education was applied was found in studies conducted in secondary school level with $77.77 \%$. This was followed in studies conducted in high schools and universities with $8.88 \%$. Studies conducted with STEM education at primary school level were found to have the lowest rate with $4.44 \%$. In terms of the level of effect size, it was found that the studies conducted in high school had the largest effect size with 1.63; while the studies conducted in university had the smallest effect size with .94 . According to this grouping, the critical value of $95 \%$ confidence interval in Chi-square table was found as 7.81. It was found that the homogeneity value (Q) between the groups formed according to the education level the studies were conducted in was 5.14. Since this value, which is the homogeneity value between groups, was smaller than the critical value, it can be said that there were no statistically significant differences in academic achievements of students in terms of the education level. 
Table 10

Findings Related to the Effect Sizes of the Application Period of the Study

\begin{tabular}{|c|c|c|c|c|c|c|c|}
\hline \multirow[b]{2}{*}{ Variable } & \multirow[b]{2}{*}{ Q } & \multirow[b]{2}{*}{$\mathrm{p}$} & \multirow[b]{2}{*}{ ES } & \multirow[b]{2}{*}{$\mathrm{n}$} & \multirow[b]{2}{*}{$\mathrm{Se}$} & \multicolumn{2}{|c|}{$\mathrm{ES}(\% 95 \mathrm{CI})$} \\
\hline & & & & & & Lower Limit & Upper Limit \\
\hline Period & 2.27 & .32 & & & & & \\
\hline 2-5 weeks & & & 1.45 & 21 & .26 & .94 & 1.97 \\
\hline 6-8 weeks & & & .74 & 4 & .34 & 1.06 & 2.41 \\
\hline $\begin{array}{l}\geq 9 \text { weeks and } \\
\text { unspecified }\end{array}$ & & & .19 & 0 & .18 & .84 & 1.53 \\
\hline
\end{tabular}

According to the results in Table 10, the highest rate according to the experimental study periods STEM education was applied was found in studies conducted between $2-5$ weeks with $46.66 \%$. This was followed by studies conducted between 6-8 weeks with $31.11 \%$. The rate of studies that lasted longer than 9 weeks and those the periods of which were not specified was found as $.02 \%$. In effect sizes of application period, the largest value was found in applications between 2-5 weeks with 1.45. This was followed with studies that lasted $\geq 9$ weeks and unspecified with .19 . It was found that the critical value of these studies at $95 \%$ confidence interval was 7.81 and the homogeneity value $(\mathrm{Q})$ between groups formed in terms of study periods was found as 2.27. Since this $Q$ value was found to be smaller than the critical value, it can be said that there were no statistically significant differences between students' academic achievement in terms of study period.

Table 11

Findings Related to the Effect Sizes of the Number of Individuals the Study was Conducted on

\begin{tabular}{|c|c|c|c|c|c|c|c|}
\hline \multirow{2}{*}{ Variable } & \multirow{2}{*}{ Q } & \multirow[b]{2}{*}{$\mathrm{p}$} & \multirow[b]{2}{*}{ ES } & \multirow[b]{2}{*}{$\mathrm{n}$} & \multirow[b]{2}{*}{$\mathrm{Se}$} & \multicolumn{2}{|c|}{$\mathrm{ES}(\% 95 \mathrm{CI})$} \\
\hline & & & & & & Lower Limit & Upper Limit \\
\hline Sample & 12.82 & .00 & & & & & \\
\hline $0-40$ & & & 1.40 & 16 & .27 & .86 & 1.94 \\
\hline $41-80$ & & & 1.04 & 23 & .13 & .78 & 1.30 \\
\hline$\geq 81$ & & & 3.35 & 6 & .65 & 2.07 & 4.63 \\
\hline
\end{tabular}

According to Table 11, experimental studies in which STEM education was applied were conducted on 41-80 individuals with the highest rate. This was followed by studies in which 0-40 individuals participated with $35.55 \%$. 6 of the studies conducted with $\geq 81$ individuals were found to have the lowest rate. It was found that the largest effect size was found in studies conducted with 81 and more individuals with 3.35. The smallest effect size was found in studies conducted with 41-80 individuals with 1.04. Critical value was found as 7.81 at $95 \%$ confidence interval and it was found that the homogeneity value $(\mathrm{Q})$ between groups formed in terms of the number of 
participants was 12.82. Since this value was larger than the critical value, a significant difference was found between students' academic achievement in terms of the number of participants in studies. According to findings, when STEM education is applied to 81 and more individuals, it can give more effective results than when it is applied to fewer or more individuals.

\section{Discussion and Conclusion}

The present study includes an analysis of studies conducted to find out to what extent STEM education applied experimentally in science courses in Turkey after the year 2018 affects students' academic achievement. As a result of the literature review, we found a total of 45 studies. In the studies reviewed, while STEM education was used in the experimental group, teacher-centred approaches were used in the control group. We did not include studies which did not have a control group and which had missing data in our study. As a result of the analyses, we found that the studies had a heterogeneous distribution and according to this result, we decided to use the REM model. When it is considered that a total of 11 studies were reached about STEM education in Turkey in a study conducted by Saraç (2018), we found that there has been a serious increase in the number of studies since 2018. Kalemkuş (2019) also stated that studies about STEM began to intensify in 2018. The most important reason for this increase is the Science Curriculum which came into effect in 2017 and was updated in 2018 because a field with the title Science, Engineering and Entrepreneurship Practices was added to this curriculum. Studies on STEM education directly associated with this field began to attract interest in all levels of education. As a result, the number of experimental studies conducted on science courses with STEM education increased approximately 4 four times compared to before 2018 .

The present study aimed to find out the general effect size of these educations that have a specific basis and application culture by analysing them with meta-analysis. Saraç (2018) analysed 27 studies in which STEM education approach was applied in science education. Saraç examined and compared the achievements of students in these analyses in terms of their attitudes and scientific process skills. The overall Hedges' $g$ effect size of STEM education was found as .44 in these studies. This result means that the effect of STEM education is significantly higher when compared with teachercentred methods. 25 of the studies the researcher analysed had positive effect size, while 2 had negative effect size. In the present study, overall effect size value of 45 studies conducted since 2018 was found as 1.48. According to Cohen et al.'s (2007, p. 521) effect size classification, this result means that STEM education had a strong effect on the academic achievement levels of students. In addition, when these results were compared with the results of the study conducted by Saraç (2018), an effect size larger than three times was found. While the effect size of 44 studies in the present study was positive, only 1 study was found to have negative effect. In their study, Becker and Park (2011) reached 28 studies and found that 7 had negative effect, while 21 had positive effect and that overall effect size was moderate (.63). All these results show that STEM education has a larger effect size than teacher-centred approaches in increasing the academic achievement of students in science courses. In addition to these, Young, Ortiz and Young (2017) examined 15 studies to conduct a meta-analysis of students' interest levels for science courses and found that the overall effect of these studies was 1.03. 
Comparisons were made by forming sub-categories for the studies in the research. The first of these comparisons is the type of publication. According to classification made as article, master's thesis and doctorate thesis, the largest effect size was found in doctorate theses. Effect sizes according to master's theses and articles were found to be close to each other. According to all of these three groups, STEM education has a large effect on developing the achievement of students in science courses. It can be said that the reason why the effect sizes of doctorate theses were larger than master's theses is that researchers gain experience and minimize external factors and plan experimental process better. In Saraç's (2018) study, 9 of 11 studies were classified as article, while 2 were classified as master's thesis and it was found that theses had large effect, while articles had moderate effect. It can be said that this result and the results of the present study are consistent with each other.

When the effect sizes of the studies included in the present study were analysed, it was found that studies conducted in 2019 had larger effect size. When these effect sizes were examined, it was found that studies conducted in 2019 had significantly larger effect size in increasing academic achievement when compared with studies conducted in 2018. Saraç (2018) also concluded that studies conducted in 2018 had larger effect size when compared with the studies conducted previously. This result can be associated with the fact that the number of studies related with STEM education has increased in years (Banning \& Folkestad, 2012, p. 732). In addition, the fact that researchers design their experimental studies more carefully and more elaborately by taking into consideration the recommendations of previous studies can be associated with the higher academic achievement of students.

The results of analyses performed for the other sub-categories of the study are as follows: The effect size of STEM education applied by teachers is larger than the applications of other researchers. While the subject area with the largest effect size was biology, the subject area with the smallest effect size was science. Effect sizes of studies conducted in physics and chemistry were also found to have large effect size according to classification by Cohen (2007). When the results of the meta-analysis by Saraç (2018) and the results of the present study were compared, it was found that both studies had moderate effect size in science. In their study, Becker and Park (2011) analysed the results of 13 studies conducted in the subject area of science and found that 5 of these studies had large effect size, while 8 had moderate and small effect size. This result can be evaluated as studies showing consistency in terms of the subject area.

In the comparisons made in terms of the education level STEM education was applied; the largest effect size was found in studies conducted on high school students, while the smallest effect size was found in studies conducted on university students. In addition, the effect size found in all education levels was found to be large. The results of the analysis of 18 students by Saraç (2018) are partly in parallel with the results of the present study. Saraç, who found only one study at university level, found that this research, had moderate effect level. It was stated that 16 of 18 studies were conducted on high school students and the effect size was small. In their meta-analysis, Becker and Park (2011) stated that there were studies with large and small effect size in all education levels. It was shown by authors that the largest and smallest effect size values were found in studies conducted in high school level. In a study conducted by Young, Ortiz, and Young (2017), it was found that the effect size of students' interest in STEM according to their grades did not show a specific tendency in terms of the increase or 
decrease in grades. In addition, it was also found in another study that STEM applications out of school positively affected students' interest in STEM education. (Timur, Timur, Yalçınkaya-Önder, \& Küçük, 2020). When the results of these studies are examined, it can be said that there is no specific tendency in effect size in terms of the education level of students. It can be said that this situation results from the fact that factors other than education levels are more effective in studies' effect sizes.

When the effect sizes of application times were compared in the study, it was found that the largest effect size occurred in studies that lasted 6-8 weeks. Studies with less than five weeks of application period had the smallest effect size. In terms of the groups formed in the study, it can be seen that the increase or decrease in the application period of the experimental study did not create a tendency in terms of effect size. In other words, the change between the length of study period and size effect values is not directly proportional. The fact that problems such as loss of motivation and attention occur as study period increases can negatively influence education states. It can be said that the reason why the smallest effect size occurred in studies with short application period results from low adaptation of students to STEM applications and the inexperience of the teacher in managing this process. The reason why effect size decreases after nine weeks can be the fact that students have too much responsibility in STEM education and that these practices, which seem different after a specific time, become tiring for students.

Another result of the study is the comparison of effect sizes in terms of the number of students who participated in experimental studies. In terms of the number of participants, the largest effect size was found in experimental studies with 76-100 participants. The smallest effect size was found in studies with less than 50 participants and in studies with 51-100 participants. It was stated in studies that increase in sample size contributed to the increase in effect size because this way, the accuracy and power of parameter estimations also increased (Hedges \& Olkin, 1980). However, although increasing the number of participants to a large extent increases the external validity of the study, it can also cause the emergence of threats that are effective on internal validity, such as loss of subject and becoming mature (Karasar, 2005).

\section{Implications}

The present meta-analysis examined the effect of STEM education practices on students' academic achievement. Other variables frequently addressed, such as attitude, motivation, and scientific process skills, were not included in the scope of the study. It is predicted that it will be useful to analyse the effects of STEM education on other cognitive, affective and psycho-motor skills in addition to academic achievement because academic achievement is not a skill that occurs alone. It can be affected by both different cognitive skills and affective and psycho-motor skills directly and indirectly.

According to meta-analysis results, it can be seen that STEM education has a large effect size in increasing success in science courses. This result can contribute to teachers' using STEM education model, which is a contemporary teaching model, in science courses that have a low level of student achievement in general (Yaman, 2017).

In the present study, master's theses were found to make the greatest contribution. Considering that STEM education has about 5-6 years of past in Turkey, it can be assumed that the error levels on results will decrease especially with the increase in doctorate studies. For this reason, it will be useful for researchers to prefer STEM 
education, especially at doctorate level, to reach less erroneous results of effect size. One of the most important indicators of this recommendation can be shown as the increase in effect size level as years advance because researchers conduct more controlled studies by considering correct and incorrect procedures.

A great majority of the studies analysed in the present study were obtained from studies conducted by teachers. Since teachers conduct both teaching activities and experimental activities together, it can be expected for errors in results to be higher. For this reason, an increase in studies conducted by academic staff at universities can be effective in decreasing the amount of error in meta-analysis results. In addition, it was found that the subject area most discussed in studies was physics. It can be said that this is because physics includes more concrete subjects when compared with the other areas of science. In addition, a great majority of these studies were found to be conducted at secondary school level. It is expected that increasing the number of studies conducted in both other education levels and biology and chemistry fields will give more correct results in terms of finding out the effect size for science with STEM education.

The results of the present study show that an application period of 6-8 weeks contributed to getting more effective results. Considering that most of the studies were conducted in secondary school and based on units, it can be suggested that this situation is normal because each unit of science course in basic education (12 years of primary, secondary and high school education) in Turkey include a period of 6-8 weeks (MEB, 2018). A large number of researchers considered this result in meta-analysis as normal since experimental studies were prepared by taking only one unit into consideration. For this reason, it can be said that for researchers who will carry our experimental studies on STEM education, designing 6-8 weeks long studies for one unit will help to get effective results. In addition, it is predicted that instead of working with very small or very large groups, designs with 76-100 participants will contribute to increase in effect size.

Some of the studies which were planned to be analysed in the present study were not accessed and it was not possible to include some studies due to missing data in them. Researchers' sharing their study is a necessity for qualitative study paradigm because experimental studies are studies in which results are expected to be generalized. The study conducted by each researcher will make significant contributions to reach the population parameters. Researches with missing data are not suitable for qualitative paradigm, and also, they should not be in a scientific study. It is thought that researchers who conduct such studies with missing data should be more careful and attentive about basic statistics that should be presented in a scientific publication and this should be provided with the supervision of editors and reviewers in articles and the jury in theses.

The scope of this research, consists of master's and doctorate theses and scientific articles published only in Turkey. Comparing the results of this research, with studies conducted abroad will make positive contributions for the generalizations of the results of STEM education, which is known to be applied intensively in the whole world since 2010.

\section{Statement of Responsibility}

Şadiye Karaşah Çakıcı; analysis, methodology, data collection, validation, resources, writing - original draft, writing - review \& editing, visualization. Özge Kol; conceptualization, methodology, data collection, validation, writing - original draft, 
writing - review \& editing, supervision. Süleyman Yaman; design of the project, project administration, resources, writing - review \& editing, supervision.

\section{References}

*Akçay, S. (2018). The effects of robotic STEM application on science teachers' academic success, scientific process skills, and motivations (Unpublished master's thesis). Muğla Sitkı Koçman University.

*Akkaya, M. M. (2019). The effect of STEM activities that applied in force and motion unit on the strength, attitude, and opinions of 6th-grade students (Unpublished master's thesis). Gazi University.

*Alinak-Bozkurt, H. (2018). The effect of engineering design-based science instruction on 7th-grade students' science achievement, their attitudes towards STEM fields, and their STEM career perceptions (Unpublished master's thesis). Kafkas University.

*Alp, A. T. (2019). The effect of STEM applications on physics success: Pressure (Unpublished master's thesis). Necmettin Erbakan University.

Ayas, A. (1995). A study on program development and application techniques in science: Evaluation of two contemporary approaches. Hacettepe University Journal of Education, 11, 149-155.

Aydagül, B., \& Terzioğlu, T. (2014). Importance of science, technology, engineering and mathematics. TÜSİAD Journal of Opinion, 85, 13-19.

*Aygen, M. B. (2018). STEM applications for supporting integrated teacher knowledge of science teacher candidates (Unpublished master's thesis). Firat University.

*Aysu, G. (2019). An examination of the effects of a problem-based learning STEM application on students' academic achievements and permanence of learning (Unpublished master's thesis). Niğde Ömer Halis Demir University.

*Bahşi, A. (2019). The effects of STEM activities on scientific process skills, scientific epistemological beliefs, and science achievements of 8th-grade students (Unpublished master's thesis). Adıyaman University.

Banning, J., \& Folkestad, J. E. (2012). STEM education-related dissertation abstracts: A bounded qualitative meta-study. Journal of Science Education and Technology, 21(6), 730-741. https://doi.org/10.1007/s10956-011-9361-9

Becker, K., \& Park, K. (2011). Integrative approaches among science, technology, engineering, and mathematics (STEM) subjects on students' learning: A metaanalysis. Journal of STEM Education: Innovations and Research, 12(5), 23-37.

Belland, B. R., Walker, A. E., Kim, N. J., \& Lefler, M. (2017). Synthesizing results from empirical research on computer-based scaffolding in STEM education: A meta-analysis. Review of Educational Research, 87(2), 309-344. https://doi.org/10.3102/0034654316670999

Borenstein, M., Hedges, L. V., Higgins, J. P. T., \& Rothstein, H. R. (2009). Introduction to meta-analysis. John Wiley and Sons Publication.

Breiner, J. M., Harkness, S. S., Johnson, C. C., \& Koehler, C. M. (2012). What is STEM? A discussion about conceptions of STEM in education and partnerships. School Science and Mathematics, 112(1), 3-11. https://doi.org/10.1111/j.1949- 
8594.2011.00109.x

*Buyruk, B. (2019). The effect of STEM education on student success and some variables (Unpublished master's thesis). Amasya University.

*Büyükbastırmac1, Z. (2019). The effect of STEM applications used in power and unit in 7th grades on success, attitudes, and motivation (Unpublished master's thesis). Necmettin Erbakan University.

*Büyükdede, M. (2018). Effect of the STEM activities related to work-energy and impulse-momentum topics on academic achievement and conceptual understanding level (Unpublished master's thesis). Dokuz Eylül University.

*Büyükdede, M., \& Tanel, R. (2018). Effect of the STEM activities related to impulsemomentum topics on academic achievement Electronic Turkish Studies, 13(27), 327-340. https://doi.org/10.7827/TurkishStudies.14283

Bybee, R. W. (2010). What is STEM education? Science, 329(2), 995-996.

Cohen, J. (1988). Statistical power analysis for the behavioural sciences. Academic Press.

Cooper, H. (2015). Research synthesis and meta-analysis: A step-by-step approach (4 ${ }^{\text {th }}$ Ed.). Sage Publication.

Czerniak, C. M., Webber, B. W., Sandmann, A., \& Ahern, J. (1999). A literature review of science and mathematics integration. School Science and Mathematics, 99(8), 421-430. https://doi.org/10.1111/j.1949-8594.1999.tb17504.x

*Çalışıc1, S. (2018). The effects of STEM applications on the environmental attitudes of the 8th year students, scientific creativity, problem-solving skills and science achievements (Unpublished doctoral dissertation). Gazi University.

*Çetin, S. (2019). The effect of STEM education on the academic achievement of secondary school students (Unpublished master's thesis). Necmettin Erbakan University.

Çetink1l, H. (2017). The impact of biology teaching based on multiple intelligence theory on academic achievement: A meta-analysis study (Unpublished master's thesis). Gazi University.

*Çimentepe, E. (2019). The effect of STEM activities on academic achievement, scientific process skills, and computational thinking skills (Unpublished master's thesis). Niğde Ömer Halis Demir University.

*Dall1, A. (2019). Instructional design based on the STEM approach on substance cycles and environmental problems (Unpublished master's thesis). Uludağ University.

*Dedetürk, A. (2018). Developing, implementing, and investigation of achievement in the 6th grade sound subject teaching activities by STEM approach (Unpublished master's thesis). Erciyes University.

*Dedetürk, A., Kırmızıgül, A. S., \& Kaya, H. (2020). The effect of STEM activities on students" achievement in "sound" subject. Pamukkale University Journal of Education, 49, 134-161. https://doi.org/10.9779/pauefd.532331

*Demircioğlu, M. (2019). The effect of student achievement of project-based STEM approach used in the teaching of water and life subject (Unpublished master's thesis). Necmettin Erbakan University. 
Dinçer, S. (2014). Applied meta-analysis in educational sciences. Pegem Academy.

*Doğan, İ. (2019). Determine the effect of science, technology, engineering, and mathematics (STEM) activities on the academic success in the science course, science process skills, attitudes towards science subjects, and attitudes towards the STEM of the 7th-grade students (Unpublished doctoral dissertation). Balikesir University.

*Dumanoğlu, F. (2019). Effect of science, technology, engineering, and mathematics activities on seventh-grade students' academic achievement and attitudes (Unpublished master's thesis). İstanbul University.

Durlak, J. A. (1995). Understanding meta-analysis. L. G. Grimm \& P. R. Yarnold (Eds.). Reading and understanding multivariate statistics (pp. 319-352). American Psychological Association.

Durlak, J. A., \& Lipsey, M. W. (1991). A practitioner's guide to meta-analysis. Plenum Publishing Corporation.

*Eroğlu, S. (2018). The effect of STEM implementations in atom and periodic system unit on academic achievement, scientific creativity, and nature of science (Unpublished doctoral dissertation). Erciyes University.

*Gazibeyoğlu, T. (2018). Investigation of the effect of STEM applications on achievement in force and energy unit and attitudes towards science course of 7thgrade students (Unpublished master's thesis). Kastamonu University.

*Gülen, S., \& Yaman, S. (2019). The effect of the integration of STEM disciplines into Toulmin's argumentation model on students' academic achievement, reflective thinking, and psycho-motor skills. Journal of Turkish Science Education, 16(2), 216-230.

*Gülhan, F., \& Şahin, F. (2016). The effect of science-technology-engineeringmathematics integration (STEM) on 5th-grade students' conceptual understanding and their views on professions. In Ö. Demirel. \& S. Dinçer (Ed.) Innovations in education science and search for qualification (pp. 283-302) Pegem Academy.

*Gündoğdu, K., F. (2019). Preparing and applying instructional design with STEM approach 'Electricity in our life' in the 8th-grade science course (Unpublished master's thesis). Gazi University.

*Gürbüz, F., Gökçe, Y., Töman, U., Gürbüz, S., \& Gökçe, F. (2019). The effect of STEM applications on academic success and permanence in science lesson solar system and beyond. Journal of Instructional Technologies and Teacher Education, $8(2), 21-29$.

*Güven, Ç., Selvi, M., \& Benzer, S. (2018). Teaching applications based on 7e learning model centered STEM activity effect on academic achievement. Anemon Mus Alparslan University Journal of Social Sciences, 6(STEMES'18), 73-80. https://doi.org/10.18506/anemon.463812

Hançer, A. H., Şensoy, Ö., \& Yıldırım, H. İ. (2003). An evaluation about the importance of contemporary science education at elementary schools and how this kind of science teaching. Pamukkale University Journal of Education Faculty, 1(13), 80-88.

*Hebeci, M., T. (2019). The impacts of science, technology, engineering, and 
mathematics applications on middle school students' academic achievement, scientific creativity and attitudes (Unpublished doctoral dissertation). Necmettin Erbakan University.

Hedges, L. V., \& Olkin, I. (1980). Vote-counting methods in research synthesis. Psychological Bulletin, 88(2), 359-369. https://doi.org/10.1037/0033-2909.88.2.359

Huffcutt, A. (2002). Research perspectives on meta-analysis. In S. G. Rogelberg (Ed.), Handbook of research methods in industrial and organizational psychology (pp. 198-215). Blackwell Publishers.

Hunter, J. E., \& Schmidt, F. L. (2004). Methods of meta-analysis: Correcting error and bias in research findings (2nd Ed.). Sage Publication.

Littell, J. H., Corcoran, J., \& Pillai, V. (2008). Systematic reviews and meta-analysis. Oxford University Press.

*Irak, M. (2019). Examining the effect of STEM applications for the "diffusion of light" unit of the 5th-grade science course on academic achievement and attitude towards STEM (Unpublished master's thesis). Kocaeli University.

*İnce, K., Misır, M. E., Küpeli, M. A., \& Firat, A. (2018). Examining the effect of STEM-based approach on the problem-solving ability and academic success of students in teaching the enigma of the earth's crust unit of the 5th-grade life sciences course. Journal of STEAM Education, 1(1), 64-78.

Kalemkuş, J. (2019). STEM Tendency in Experimental Researches. Dicle University Ziya Gökalp Journal of Education Faculty, 36, 78-90.

*Karc1, M. (2018). Examining the effect of scenario-based learning approach (story) based on STEM activities on students' academic achievement, career choices, and motivation (Unpublished master's thesis). Çukurova University.

Karasar, N. (2005). Scientific research method. Nobel publisher.

*Kayabaş, B., T. (2019). The effect of problem-based outdoor-STEM activities on the students' academic achievements and decision-making skills (Unpublished master's thesis). Muğla Sitk1 Kocman University.

Keskin, B., \& Özay-Köse, E. (2019). Examination of the sequence of physics and chemistry topics constituting the basis of biology in secondary education curriculum. Journal of Theoretical Educational Science, 12(1), 260-273. http://dx.doi.org/10.30831/akukeg.433217

Kim, N. J., Belland, B. R., \& Walker, A. E. (2018). Effectiveness of computer-based scaffolding in the context of problem-based learning for STEM education: Bayesian meta-analysis. Educational Psychology Review, 30(2), 397-429. https://doi.org/10.1007/s10648-017-9419-1

*Kurt, M. (2019). A study on the effect of STEM applications on 6th-grade students' academic achievement, problem-solving skills and attitudes towards STEM (Unpublished master's thesis). Gazi University.

Kulinskaya, E., Dollinger, M. B., \& Bjørkestøl, K. (2011). Testing for homogeneity in meta-analysis I. The one-parameter case: standardized mean difference. Biometrics, 67(1), 203-212. https://doi.org/10.1111/j.1541-0420.2010.01442.x

*Kurtuluş, M., A. (2019). The effect of STEM activities on students' academic achievements, problem-solving skills, scientific creativity, motivations, and 
attitudes (Unpublished master's thesis). Alanya Alâeddin Keykubat University.

Lipsey, M. W., \& Wilson, D. B. (2001). Practical meta-analysis. Sage Publications

Lodico, M. G., Spaulding, D. T., \& Voegtle, K. H. (2006). Methods in educational research: From theory to practice. John Wiley \& Sons, Inc.

McComas, W. F., \& Murie, K. (2014). Science education. In W. F. McComas (Ed.), The language of science education (pp. 86-87). Sense Publishers.

Miles, M. B., \& Huberman, A. M. (1994). Qualitative data analysis: An expanded sourcebook. Sage Publication.

Ministry of National Education [MEB]. (2016). STEM education report. Ankara: Ministry of National Education, General Directorate of Innovation and Educational Technologies (YEĞİTEK).

Ministry of National Education [MEB]. (2017). Science course curriculum. Ministry of National Education.

Ministry of National Education [MEB]. (2018). Science course curriculum. Ministry of National Education.

Moore, T. J., Glancy, A. W., Tank, K. M., Kersten, J. A., \& Smith, K. A. (2014). A framework for quality K-12 engineering education: Research and development. Journal of PreCollege Engineering Education Research, 4(1), 1-13. https://doi.org/10.7771/2157-9288.1069

Mustafa, N., Ismail, Z., Tasir, Z., \& Said, M. N. H. M. (2016). A meta-analysis of effective strategies for integrated STEM education. Advanced Science Letters, 22(12), 4225-4228. https://doi.org/10.1166/asl.2016.8111

Murphy, K.R. (2003). Validity generalization a critical review. London: Lawrence Erlbaum Assocites Publishers.

*Nağaç, M. (2018). Investigation of the effect of science, technology, engineering, and mathematics (FeteMM) education on students' academic achievement and problem-solving skills in the teaching of the 6th-grade science lesson item and heat unit (Unpublished master's thesis). Hatay Mustafa Kemal University.

*Neccar, D. (2019). Effects of STEM activities of science lessons on middle school students' achievement, attitude towards science and their opinion about STEM (Unpublished master's thesis). Gazi University.

OECD. (2019). PISA 2018 results (volume I), what students know and can do. OECD Publishing. https://doi.org/10.1787/5f07c754-en.

Olkin I., 1996. Meta-analysis: Current Issues in Research Synthesis. Statistics in Medicine, 15(12), 1253-1262.

Okursoy-Günhan, F. (2009). The effect of concept mapping on learner success: A metaanalytic study (Unpublished master's thesis). Marmara University.

*Ozan, F. (2019). An investigation of STEM application efficiency related to different variables towards 5th-grade unit measuring the force and friction (Unpublished master's thesis). Amasya University.

*Özcan, H., \& Koca, E. (2019). The impact of teaching the subject "pressure" with STEM approach on the academic achievements of the secondary school 7th grade students and their attitudes towards STEM. Education and Science, 44(198), 201- 
227. https://doi.org/10.15390/EB.2019.7902

Özdemirli, G. (2011). The effect of cooperative learning up on mathematical achievement and attitude: A meta-analysis of findings (Unpublished master's thesis). Çukurova University.

*Özlen, S. (2019). Developing design-based STEM activities and evaluating the activities on simple machines at the eighth-grade level (Unpublished master's thesis). Muğla Sitkı Koçman University.

Rosenthal, R. (1984). Meta-analytic procedures for social research. Sage Pub

Sanders, M. (2009). STEM, STEM education, stemmania. The Technology Teacher, 68(4),20-26.

Saraç, H. (2018). The effect of science, technology, engineering, and mathematicsSTEM educational practices on students' learning outcomes: A meta-analysis study. Turkish Online Journal of Educational Technology-TOJET, 17(2), 125-142. https://doi.org/10.29333/iejme/5885

Schulze, R. (2004). Meta-analysis a comparison of approaches. Hogrefe and Huber Publishers.

*Soysal, M., T. (2019). Thematic STEM education in 8th-grade science course: Earthquake Example (Unpublished master's thesis). Sakarya University.

Strategy and Budget Department of the President of the Republic of Turkey. (2019). Eleventh development plan 2019-2023. http://www.sbb.gov.tr/wpcontent/uploads/2019/11/on_birinci_kalkinmaplani_20192023.pdf.

*Şen, N. (2019). The effects of STEM-based learning environment on science learning in 7th-grade electrical energy unit (Unpublished master's thesis). Uşak University.

*Taşç1, M. (2019). Investigation of the effects of reverse engineering applications on academic achievement, problem-solving skills, STEM attitudes, and perceptions in 8th-grade students (Unpublished master's thesis). Marmara University.

Timur, S., Timur, B., Yalçınkaya-Önder, E., \& Küçük, D. (2020). Attitudes of the students attending out-of-school STEM workshops towards STEM education. Journal of Theoretical Educational Science, 13(2), 334-351. https://doi.org/10.30831/akukeg.582388

TÜSİAD (2017). 2023 towards STEM requirement in Turkey. http://www.tusiadSTEM.org/images/raporlar/2017/STEM-RaporuV7.pdf

*Uçar, R. (2019). Effects of the STEM activities enriched with argumentation at 7thgrade students' academic achievement on 'solar system and the beyond' unit, astronomy attitudes, critical thinking tendency, and STEM career interest (Unpublished master's thesis). Adnan Menderes University.

United Nations Educational, Scientific, and Cultural Organization [UNESCO]. (2015). Education for all 2000-2015: Achievements and challenges, France. https://doi.org/10.1126/science. 1128690

Yaman, S. (2017). Science teachers' opinions on the application of competency-based science model components to science programs. The International Journal of Evaluation and Research in Education, 6(2), 118-127. http://doi.org/10.11591/ijere.v6i2.7590 
Yeşilyaprak, B. (2006). Counselling services in education (14th). Nobel Publisher.

Yıldırım, A., \& Şimşek, H. (2011). Qualitative research methods in the social sciences. Seçkin Publisher.

Y1ldirım, B. (2016). An examination of the effects of science, technology, engineering, mathematics (STEM) applications, and mastery learning integrated into the 7thgrade science course (Unpublished master's thesis). Gazi University.

*Y1ldirım, B., \& Altun, Y. (2015). Investigating the effect of STEM Education and engineering applications on science laboratory lectures. El-Cezeri Journal of Science and Engineering, 2(2), 28-40. https://doi.org/10.13140/RG.2.1.2296.0800

Y1ldiz, N. (2002). Meta-analysis method in data evaluation (Unpublished master's thesis). Marmara University.

*Y1lmaz, C. (2019). The effect of STEM education on 10th-grade students' academic success, their attitude towards STEM, and physics (Unpublished master's thesis). Pamukkale University.

Y1lmaz, H., Yiğit-Koyunkaya, M., Güler, F., \& Güzey, S. (2017). Turkish adaptation of the attitudes toward science, technology, engineering, and mathematics (STEM) education scale. Kastamonu Education Journal, 25(5), 1787-1800. https://doi.org/10.1007/s10798-011-9160-х

Young, J. R., Ortiz, N. A., \& Young, J. L. (2017). Stimulating interest: A meta-analysis of the effects of out-of-school time on student STEM interest. International Journal of Education in Mathematics, Science and Technology, 5(1), 62-74. https://doi.org/10.18404/ijemst.61149

*Yüksel, F. (2019). The effect of STEM applications outside the classroom on students' learning products in a secondary school science course (Unpublished master's thesis). Ondokuz Mayıs University.

This is an Open Access article distributed under the terms of the Creative CommonsAttributionNonCommercial-ShareAlike 4.0 International (CC BY-NC-SA 4.0). For further information, you can refer to https://creativecommons.org/licenses/by-nc-sa/4.0/ 